\title{
Vernacular Religions and the Invention of Identities Behind the Finno-Ugric Wall
}

\author{
KRISTIN KUUTMA \\ University of Tartu
}

\begin{abstract}
In the following I discuss vernacular religion as a tool for contesting and manifesting identities in Estonia. The study takes a look at an overwhelming impact of the Soviet system of state atheism combined with constraining sociopolitical norms and oppression of cultural individuality on the religious ideology that emerged in the modern, secularised Estonian society under the Soviet rule. In such a context vernacular forms of religiosity were perceived and practised in Estonia with obvious political connotations. After regaining independence on August 20, 1991 this ideology of opposition has not ceased, but carried on up to the present-day. This analysis of interdisciplinary approach will focus on the historical overview of the emergence of particular religious movements, though the main emphasis will be placed on developments in the 1990s. The given examination draws mostly on published material and documented manifestations available in print, as well as on ethnographic observation of social interaction, although no individual or detailed interviews were carried out by the author. The aim of this contribution is therefore a general mapping of a particular situation under the circumstances of the most turbulent transitional phase in recent Estonian history, while focusing on the social visibility of those religious identities and the image projected to the general public.
\end{abstract}

\section{Strategies of self-definition}

In this article, I propose to explore the notion of 'vernacular religion'1 from the perspective of identity construction. My study distances itself from the cognitive aspect of religious experience, while drawing attention to the general socio-cultural, or even, in a more specific way, to the socio-political

\footnotetext{
${ }^{1}$ My grasp of the term of 'vernacular religion' derives from the elaboration by Leonard Primiano, who suggests analysing "religion as it is lived: as humans encounter, understand, interpret and practice it" (Primiano 1995, 44).
} 
context of the emergent conceptions and designations. I will not analyse belief or praxis, but instead discuss vernacular religion as a tool for contesting and manifesting identities in Estonia. The ontology of vernacular religions in this society in transition involves a dynamic contestation of cultural traditions and religious metanarratives, of knowledge and practices. The current survey, however, cannot portray the whole array of contemporary vernacular spirituality, but focuses rather on a religious system that is inherently connected to the display of national identity by highlighting idiosyncratic cultural heritage. At the same time, that heritage is perceived as manipulated and ultimately threatened by 'official' religions, and so the active practitioners have felt the necessity to work out an ideology of, and eventually build an environment for, the preservation and promotion of the perceivably genuine, 'the true' essence of national culture.

The vernacular religions are also examined here with reference to the new religious movements in the West that became publicly visible in the mid-1960s as part of the general phenomenon of 'counter-culture', though the more theologically oriented forms took shape largely in the 1970s. It has been claimed that by being a reaction to, or a reflection of, contemporary society, by meeting the neglected psychological or spiritual needs, or by heralding the anticipation of a new era, these movements were particularly characteristic of the US, but also of Britain, West Germany and Austria, while being entirely absent in Eastern Europe (e.g., see Hinnells 1984, 232-233). However, I propose to argue that the last proposition needs to be revised. Apparently such movements behind the Iron Curtain found no official coverage at the time, and remained invisible to western scholars. In the Baltic countries, for example, analogous movements inherently coalesced with most sensitive identity issues: with national or cultural evaluative and emotional characteristics from which people derived their sense of knowing or belonging, with common categories and salient heritage by which they defined themselves.

From a geopolitical perspective, Estonia is destined to occupy a marginal position, and through the course of its turbulent history Estonians have had 
to reconceptualize their identity time and again. In the alternating periods of rising or declining hegemonies new cultural strategies for the negotiation of selfhood have appeared, alongside with a desire for new identities. Constitution of identity is in itself an elaborate game of mirrors (Friedman 1992, 853), where people define themselves socially, politically or culturally in relation to others or to the outside world. Those mirrors are situated in space and time, through which people construct for themselves a history and a future that represents and manifests them for the others. On the other hand, the cultural strategies of self-definition and self-maintenance reflect interplay between local and global processes, and the constitution and presentation of the self for others is therefore always argumentative in nature (cf. Friedman 1994; Anttonen 1996). Cultural identities are produced in a wider discourse of political rights; they manifest a reaction to the political and administrative authority of homogenization. Intensive negotiation of identity appears under conditions of cultural and political marginalization, when a community feels endangered from without and sets about defining its cultural boundaries as a strategy of self-defence. Identities are constructed and negotiated in the discursive context of interrelations or oppositions; it is in fact a relative and dialogical process with "the other", a process of constitution of self for others. The internal self-definition reflects the community's self-representational ideals, it mediates a narrative of genesis by which people situate and establish themselves in a wider global context.

A survey of cultural identity in Estonia during the period of 1990 till 1997 claimed that an apparent shift had appeared in the general cultural awareness of Estonians (Suni 1998). The ethnocentric nationalism and collectivism of ideas had disappeared, to be replaced by cosmopolitan and postmodern lifestyles, the emergence of new subcultures and a global awareness. The cultural focus, coercively oriented towards the east for the previous fifty years, had now turned towards the west with full official recognition of Estonia's pending acceptance into the process of political and economic integration with Europe. It seemed that previous constructs of identity were disintegrating as new ones emerged: the strategies of self-definition 
and self-maintenance that depended on internal and external objectives of identification gave way to categories ranging from Estonian, or Baltic, or post-Soviet to European. However, the global process of homogenization, an ideology of abstract rationality and continuous campaigns for promoting development antithetically simultaneously supported the existence of anti-European assertions. In the modern world of multiple choices not everybody can or even wants to adjust to the latest reorientation of ideals. In a period of transition, in a liminal situation of the fragmentation of the everyday world, people also express their frustration by the resurgence of local and alternative cultural identities. They have felt the need to recreate and revitalize an identity oriented towards the past, in order to compensate for the insecurity they experienced in the present (cf. Frykman 1995). The alternative self-definition analyzed in this particular case embraces the evolution and maintenance of a Finno-Ugric identity that was perceived to carry the original essence of Estonian-ness, and to safeguard against the threatening dominant "other". The empowering effect of the mythical Finno-Ugric identity still continues to be instrumental: embedded in the general ideology of ethno-nationalism, Estonians have tacitly sought to build an imagined "Finno-Ugric wall". ${ }^{2}$

The Finno-Ugric affinities - originally founded on linguistic ties, gaining scholarly ground in the 1800s - played a significant role as a cultural and political manifestation in different waves during the twentieth century. It emerged strongly as an alternative ideology in Estonia with the initial phase of modernism in the first decades of the 1900s when European self-reflection had given rise to certain alternative conceptions of the truth of life being hidden in mythic pasts of modern nations (see Hughes 1977). The pure and primeval Estonian identity could be traced in the folklore of the less urbanized and industrialized kindred peoples, or in the epitomized monuments of pristine culture, in the national epics of the Estonian Kalevipoeg and the Finnish Kalevala. The Finno-Ugrian heritage functioned as an emergent

\footnotetext{
${ }^{2}$ In October 1998 the Estonian National Museum opened an exhibit Soome-ugri müür 'The Finno-Ugric Wall' to display cultural and political histories of the Finno-Ugric peoples.
} 
counterculture to oppose the previous hegemony of Baltic-German culture. Various artists and intellectuals promoted Finno-Ugrian identity; but especially active in this respect were folklorists. For example, Oskar Loorits, the founder of the Estonian Folklore Archives, idealized ancient Estonians as Finno-Ugrians who existed in total harmony with each other and with nature, while he regarded modern Estonians (particularly the urban and literate) as corrupted by Indo-European, i.e. German, culture (Tedre 1995, 458). At the turn of the twenties and thirties various cultural organizations emerged to promote kinship relations, generally denoting at the time closer cultural contacts with Finland and Hungary (the Fenno-Ugria Foundation, the Pan-Finno-Ugrian Festival, a cultural congress of Finno-Ugrians). After Estonia was annexed by the Soviet Union in 1940, all these voluntary and political organizations were banned, including those promoting any international communication.

\section{Reconceptualized Finno-Ugrianism}

A new potential rise in self-sustenance and self-presentation could develop only after the political thaw of the sixties, when Finnish scholars and artists started visiting Estonia and a few individuals on the Estonian side were granted opportunities to travel abroad. Closer ties were formed with Hungary, as both countries had to struggle against Russia's cultural hegemony. But the major development in the reconstruction of the Finno-Ugric identity was the move to the east, the rising interest for Finno-Ugrians dispersed in Russia from Karelia to the other side of the Ural Mountains. The powerful emergence of the Finno-Ugric identity as a cultural marker was a result of both local and global processes, a product of their interaction. On the one hand, in the context of the semi-colonial Soviet cultural practice Estonians felt their identity threateningly marginalized, that they were losing their ontological foundations, and finding other peoples facing similar (or, for that matter, even worse) existential perils helped sustain a precarious selfesteem. The intensive manifestation of Finno-Ugric identity in arts and culture became a political instrument in the presentation of selfhood and in the 
constitution of that selfhood. It concurred with the struggle for authenticity in cultural expression to oppose the de-authenticating decontextualization of the over-politicized Soviet culture. On the other hand, the movement to re-establish cultural identities after the decline of previous hegemonies, the reconceptualization of marginalized cultural selfhood, the engagement in authenticity and traditionalism was observable in the 1970s in various parts of the world (see Friedman 1994).

The reinvention of the Finno-Ugric identity of Estonians concurred with a general process of ethnic and cultural fragmentation, negotiation of selfhood, expressive manifestations of identity and the contested narratives of national history. ${ }^{3}$ Academic intellectuals, artists and writers became active participants in establishing the powerful image of the past golden age of the Finno-Ugrians: they had experienced remarkable closeness to nature, be it in the forest regions extending from the Baltic Sea to the Volga River, in the Arctic north, or in the Siberian tundra; the Finno-Ugrian character was defined by submissive and poignantly peaceful features, and represented a generally harmonious lifestyle governed by pristine purity. Thus it was assumed that Estonians, too, could regard the archaic elements in the cultures of all Finno-Ugrians as part of their own heritage, starting with Finnish-Karelian epic songs and ending with the bear-ceremonials of the Khants. The permeating ideology was to reject and oppose anything even remotely reminiscent of Russian culture, when it could not be explained as a borrowing from other Finno-Ugrians. And scholars studying culture, particularly folklore or ethnology, were expected to carry out comparative research on Finno-Ugric material in their field if they intended to make any substantial claims about the Estonians (cf. Rüütel 19974; see also Viires \&

\footnotetext{
${ }^{3}$ One cannot avoid noticing here the fact that similarities in historical experience or the obvious geographic ties to the south with the Baltic neighbours of Latvians or Lithuanians remains completely neglected in this discourse, but this relatively complicated topic requires more space for an appropriate elaboration of the exclusions or inclusions that occurred. Still, the mere notion of denial of Baltic affinities in the perception of vernacular identity or religious convictions serves as a vivid example of the characteristic constructs of self-representation.

${ }^{4}$ When discussing the historical layers of Estonian folk songs regilaul, their archaic origin has mainly been demonstrated on comparative Balto-Finnic archaeological and linguistic evidence.
} 
Tedre 1998). In 1960 the first World Congress of Finno-Ugric Studies met, while the third one was held in Tallinn in 1970; the Estonian National Museum started their extensive collecting expeditions to the Finno-Ugrians in Russia in the sixties (Viires \& Tedre 1998, 32). Artists, musicians and creative writers who could not address Estonian identity directly found a means of actively creating, constructing and promoting a cultural identity that could manifest a counter-selfhood as opposed to the levelling Soviet cultural ideology. Finno-Ugrianism was adopted into Estonian professional and folk culture as a means of expressing the oppressed national identity, and as an aspiration of providing one's people with an original, countercultural context in opposition to the mainstream Soviet reality. But at the same time it provided a small culture with a noteworthy position from an international and historical perspective by affiliating Estonians with Finns and Hungarians, therefore tacitly suggesting a cultural link with the West. Interpretations of the Finno-Ugric musical heritage by Veljo Tormis, the mezzotint-series by Kaljo Põllu, theatrical experiments by Jaan Tooming, poems by Jaan Kaplinski, books and documentaries by Lennart Meri, remain seminal artistic achievements of the seventies and eighties. The revitalization of the 'authentic' Finno-Ugric singing and dancing by amateur folklore ensembles, the rise of paleoastronomic interpretations of ancient myths and the growing interest in Finno-Ugric religions emerged as a cultural movement that has been called "a quest for the Finno-Ugric primeval chant" (Kõiva 1995, 218).

Tradition as a symbolic representation is constructed on the interpretation of the past in the present moment, to further particular social and ideological concerns; a tradition acquires salient significance as an interpretation of the past that is intended to render meaning to the current moment (cf. Handler \& Linnekin 1984). In a similar vein, the concept of authenticity is likewise temporal whereas the moment of authenticity is defined in the present. That is, the essence of tradition, its endorsing category of authenticity is created and determined in the present. The construction of tradition, or its invention, is essentially a process of formalization and ritualization - it is 
generally a reaction to an alteration of circumstance, and often occurs in a situation when the swift social transition weakens or destroys previously established social patterns (Hobsbawm 1983). And it is geared towards creating a unified cultural expression, with the eventual goal of establishing representative cultural symbols. Experienced periods of turbulent and unsettling social change usually create in a community a need for unifying (e.g., national) symbols that will boost the sense of connectedness with the overall goal of establishing the difference between "us" and "them". The common cultural framework created and its expressive language are based on the representation of cultural heritage as a common national symbol.

\section{From ethnic traditionalism to vernacular religion}

During the so-called second national awakening, beginning in the mid-eighties, Finno-Ugrianism became a significant element of cultural and political identity to manifest an alternative both to the disintegrating Soviet system and to the aggravating pressures of modernity. In the decline of hegemonic states, the fragmentation of the dominant ideological system is usually expressed at one level in the resurgence of local cultural identities, ethnicities and sub-nationalisms (cf. Friedman 1994). The reconceptualization of identity coincides with the making of history and the creation of national myths by foregrounding particular aspects of the past and obscuring others in order to appropriate a given content for given purposes (Anttonen 1996, 24). At the same time, the emergent cultural identities represent alternatives to a modernism that is experienced as a failure. The ancestral traditional culture becomes revered as a past that has been lost and must be regained. The past provides the medicine to cure the injuries caused by modernity; people recreate it as a compensation for the insecurity of the present confusing reality (Frykman 1995, 5). The Finno-Ugrian movement produced simultaneously a cultural and political identity supporting national cultural awareness, but it also pursued political issues. Inside the framework of the larger movement, Finno-Ugrianism also found expression in various sub-movements in pursuit of separate identity, such as the folklore move- 
ment, the green movement and neo-paganism. These movements produce an identity by concurrently conveying a message with the aim of remoralizing culture. They challenge the existing patterns in society and present alternative options (cf. Frykman 1995; Giddens 1991). In many aspects, the folklore movement, environmentalism and neo-paganism appear in Estonia combined: resistance to, and rejection of, urban (Western) civilization, celebration of archetypal pastoralism, the promotion of harmonious balance between man and nature, the combination of traditionalism and nature worship to oppose and reject the cheap values of materialist, consumerist society and international urban culture. However, the most powerful ideological quest of the primeval Finno-Ugric spirit has been manifested by the neo-pagan movement, which establishes itself as the genuine vernacular religion preserving and revitalizing vernacular Estonian culture, opposing modern dynamics and contesting the foreign cultural impact.

The followers of the neo-pagan ${ }^{5}$ movement in Estonia today refer to themselves as maausulised and to their religion as maausk, faith of the earth, or land or country, as in Estonian the word maa denotes all three. ${ }^{6}$ Occasionally there occurs the name Taarausulised, worshippers of Taara, but the latter actually denotes a preceding movement from the 1920s. ${ }^{7}$ Taara religion claimed to be a re-introduction of the genuine Estonian vernacular religion that was designed to enhance national heritage, and to create a monistic synthesis for promoting the Estonian nation and culture. ${ }^{8}$ In concurrence

\footnotetext{
${ }^{5}$ The adherents to this religion have in English also used the term 'heathen' with the patent aim to marking a distintion from the respective western movements. I am hereby applying the term 'neo-pagan' to make a distinction from other vernacular religions for the particular phenomenon discussed.

${ }^{6}$ It also carries a reference to the pre-modern vernacular term for Estonians, maarahvas 'people of the land or country'.

${ }^{7}$ The Soviet occupation banned the public activities of the Taara worshippers in 1940 and their leaders were repressed. Successors of the movement survived in exile and secretly during the whole period of occupation (see Västrik 1996, 97).

${ }^{8}$ The origin of the central figure of worship remains debated. The only documented basis for the name Taara dates to the beginning of the thirteenth-century Chronicle by Henricus of Latvia where T(h)arapita was declared the "great god of the people of Osilia", i.e. Saaremaa island. Scholars have later interpreted T(h)arapita as a battle cry Taara avita! 'Taara help us'. When the pantheon of Estonian gods was created in the middle of the nineteenth century, Taara presided as the main deity and the god of war. Taara was adopted into national poetry
} 
with the rise of the new nation-states, there appeared national activists who promoted the ideas of establishing genuinely national religions in order to achieve complete independence from cultural hegemonies, thus consciously embarking on the project of constituting 'national mythologies', as contended by Ergo-Hart Västrik who has previously studied this form of cultural expression (1996 and 1997). ${ }^{9}$ On the other hand, these inventions derived from the general turn-of-the-century modernist dissatisfaction with the over rationalization of Western society, backed up by Nietzsche's criticism of conventional Christianity, while the Western society was declared to be dying, as it had lost contact with nature, myth and symbol, with true religion and speech (Stromberg 1994, 155). The new religions created were based on a symbiosis of traditionalism - an opposition to the alienated freedom of modernity, expressed in the attempts to reinstate the values and cultural stability of a supposedly lost world - and the exotic Eastern non-Christian religions.

The more recent upsurge of neo-paganism in Estonia was largely connected with the general expansion of Finno-Ugrianism, with aspirations of a search for cultural roots, but also with the international developments, namely with the emergence of the New Religious movements in the end of the 60s. The current leaders and activists found disciples and supporters mainly among the radical academic youth (students of the arts and humanities, particularly folklore, biology, forestry, astronomy) and urban intelligentsia. But the ideology of that new phase of inventing a vernacular religion proclaimed a distinction from the Taara-believers, and expressed its adherence to folklore data deposited at the Estonian Folklore Archives and to the traditions of the Finno-Ugrian kinsfolk, while "aspiring towards the Finno-Ugric and boreal qualities" (Västrik 1996, 96). The ideological

\footnotetext{
and the reconstruction of pre-Christina history while the popularity of Taara was enhanced by schoolbooks. The etymology of Taara has been traced back to the Scandinavian Thor, but the advocates of Finno-Ugrianism would prefer to suggest a (presumably far-fetched) Finno-Ugric origin, e.g. to the Khant Torum. (Cf. Viires 1990 and Västrik 1996.)

${ }^{9}$ Similar developments where observable in Latvia and Lithuania, respectively, with the Dievturïba and Romuva movements (cf. Pūtelis 1997; Ramoškaitè-Sverdiolienè 1996). See also note 3 above.
} 
principles and the etymological paradigm of maausk ${ }^{10}$ were written down in a manifesto-like essay in 1970 (published officially only two decades later, see Eller 1990), although the followers never formed a regular or fixed organization, and thus it forked into fluid groupings that identified with different names at different periods (e.g., noortaaralased 'young Taara followers', muinastaaralased 'ancient Taara followers', metsausulised 'forest worshippers', loodususulised 'nature worshippers', etc.). The more organized, documented and publicly active period of the neo-pagan movement in Estonia began in the mid-eighties. It concurred with the overwhelming process of the so-called 'second national awakening', when it found an impressive public organizational form within the framework of the emerging heritage protection movement. The Heritage Protection Society (Muinsuskaitse Selts) developed as a new voluntary organization with officially declared cultural aims that only provided a facade for the materializing political claims for self-definition and independence. A group of rising activists of maausk registered themselves as the Heritage Protection Club Tõlet in the university town of Tartu. During the years 1987-1994 Tõlet played an important role in the neo-pagan movement and in the formation of the public image of maausk. They declared the aim of the club to be "the preservation, study and dissemination of our ancient culture in Estonia and elsewhere" (Tõlet 1992, 40). The leading activists of Tõlet were mainly students of Tartu University or the Agricultural Academy, predominantly young men in their early twenties, who in constituting their ideological principles relied heavily on the previous generation's seminal ventures: the introduction of vernacular personal names instead of international loans; ${ }^{11}$ the promotion of Sirvilauad, a traditional agrarian calendar in runic symbols, claimed to be based on the divisions of time by ancient Estonians, ${ }^{12}$ the publication of substantial

\footnotetext{
${ }^{10} \mathrm{Cf}$. with maarahvas and maakeel, which were the vernacular terms denoting Estonians and the Estonian language before the terms of 'Estonians' (eesti rahvas) and 'Estonian language' (eesti keel) were coined in mid- 1800.

${ }^{11}$ This project denoted an invention of supposedly pristine and archaic pre-Christian names with explicit etymological meaning.

${ }^{12}$ The book of names and the runic calendar were composed in the 1970s, and disseminated unofficially; the texts were officially published only in the end of the eighties (see Sarv \& Eller 1987; Kymme aastat 1988).
} 
essays heavily criticizing the mainstream orientation of the Estonian national culture (e.g., Eller 1990 and 1991). The maausulised proposed to offer a meaningful alternative to the national elite culture which was regarded as overtly European. They found a theoretical frame for their concepts in the works by the ideologists of Taara worshippers Kustav Utuste and Juhan Luiga, folklorist Oskar Loorits and folklorist-theologian Uku Masing, who had declared Western (i.e. Indo-European) civilization and culture - forcibly imposed on Estonians by Baltic German Christianization - totally and inherently alien, therefore inappropriate for Estonians (Västrik 1996, 90). Native identity needed to be re-established on the genuine native culture while denouncing alien patterns: the expressive ideals of maausulised rejected the common national culture as a German-oriented artificial invention, and proposed instead to re-establish its genuine and independent foundation based on the early Finno-Ugric tradition, which was perceived to be less contaminated by foreign influence (p. 93). They studied extensively the Estonian traditional heritage and that of kindred nations; they sought to synthesize an "intuitive Ugric feeling" that was believed to lay scattered in the depths of archives and to be inherently implemented in the lifestyle, worldview and ethics of the kindred Finno-Ugrians living in the vast expanses of Russia. The Mari, Mordvins, Udmurts, Komi, but particularly the boreal Mansi and Khants as well as the Sami in the north, were held to have retained a perception of the world that the Estonians had lost. Maausk was proclaimed to capture the essence of the Finno-Ugric identity; it was even suggested that the word identiteet of foreign origin should be replaced by maausk as its vernacular Estonian equivalent (Kaasik 1993). Its adherents aspired to revive folkloric customs or rituals, and to experience a different lifestyle as an alternative to modern urbanization. Maausulised presented themselves as bearers, revivers and interpreters of traditions, yet their movement was explicitly directed towards the future, maausk was promoted as a worldview simultaneously in harmony with contemporary life, rearranging and recreating ancient traditions for the present day: 
Heathenism is an autonomous contemporary process that emphasizes independent being and feeling; heathenism is an aspiration towards certain knowledge and apprehension through tradition; heathenism is something distant - a primordial instinct broken out, new evaluation, new order, new morals. (Cited from Västrik 1996, 93.)

The manifested principles of maausk were tolerance, responsibility, a sparing and caring attitude towards nature and other human beings, capability of developing, honesty - these "ancestral principles" were called on for guidance in everyday lives also in the twenty-first century (ibid). Tõlet practiced their activities manifestly in public and often with a demonstrative political address; Västrik has even referred to their ideology as 'aggressive heathenism' $(1996,93)$. They had carefully elaborated a cause, and targeted their objectives in the wider Estonian community to promote their agenda. In the period of 1987 to 1994 Tõlet published a newsletter under two different titles, Hiis (sacred grove) and Videvik (twilight), which continued the pre-war Taara periodicals, while a number of active members of the organization were talented writers and published frequently in the press. Maausulised refrained from copying the uniform regalia of Taara worshippers, but applied it freely in their rituals. The Taaraist symbol of sacrificial fire urituli, or the silverand-gold amulet called tôlet that contained soil from the wearer's birthplace, or tubane hiis 'indoor sacred grove' denoting a corner of a room decorated with plants for rituals, as well as stylized folk costumes, initiation of new members, and weddings were now supplemented with shamanic drumming, ritual outfits in a "Finno-Ugric" design, song repertoire in regivärss ${ }^{13}$, ritual Thursdays, and public incantation rites. Adherents of the movement developed certain inclusive features of communication: idiomatic greetings, preferences in food and beverages, clothing and hair-style ${ }^{14}$; they developed common entertainment and hobbies, promoted closeness to nature, advocated liberal rules and idiosyncratic deviance in social behaviour, or

\footnotetext{
${ }^{13}$ Estonian vernacular equivalent of the Kalevala metric poetry.

${ }^{14}$ Handmade clothes, preferably of wool; accessories and bags of natural material like leather; long braided or untied hair worn with fillets.
} 
gender relations (see Västrik 1996, 92). While ostensibly promoting a world outlook and lifestyle of primordial traditional communities, the movement concurrently manifested a postmodern reaction to pragmatic and rational modernism, and searched for alternatives in pristine wisdom, liberation of the libido and communion with nature. Parts of these manifestations coincided with, or were continuously inspired by, generational conflict, and fostered the aspirations of rebellious youth who wanted to shatter the conformist mainstream, or reflected the emergent issues of gender relations or contested positions in the modern social interaction.

The rejection of the so-called Indo-European influence or Western civilization by maausulised also found expression in their invention of an indigenous definition and reckoning of time. In the runic calendar Sirvilauad, the vernacular "creation of the world" was dated to 8213 BC, based on the occurrence of the Billingen catastrophe. ${ }^{15}$ This publication promoted the use of vernacular or dialect names for calendar months that in standard Estonian have been replaced by international terms: südakuu vs. jaanuar (January), radokuu vs. veebruar (February), urbekuu or linnukuu vs. märts (March), etc. Thus all issues of Tôlet publications carried an idiosyncratic date: for example, Hiis 6 was issued in "lehekuu 10206", i.e., in May 1993. The calendar festivals manifested in Sirvilauad and actively celebrated by maausulised were mainly based on the traditional Estonian folk (i.e. agrarian, or peasant) calendar, with the manifest objective of selecting the ones that appeared genuinely original, while avoiding those that suggested Christian holidays, ${ }^{16}$ for example: hiiepühad 'grove festival', celebration of the victory of light and valour on June 23rd/24th, and kalmuhiie päev 'day of the burial grove', celebration of the beginning of the Souls' Visiting Time on Oct 30 (cf. the list provided in Västrik 1996, 90). They particularly highlighted

\footnotetext{
${ }^{15}$ Dated by Swedish scholars within a year according to the tests with varved clay, the Billingen catastrophe demarcates the breakthrough of the Baltic Glacial Reservoir into the ocean at the site of the present-day Lake Mälar. Consequently, the greater part of Estonian terrain rose above the water level (Kymme aastat 1988). According to this time division the year 2005 is considered to be 10218 .

${ }^{16}$ Obviously a difficult task, as in the Estonian calendar rituals pre-Christian and Christian elements have completely merged.
} 
the celebration of equinoxes and solstices in the annual cycle. Maausulised recreated and redefined rites and customs as described in folklore archives for their celebrations and festivals, embellishing the "genuine" Estonian tradition with exotic borrowings from various Finno-Ugric cultures. For example, three wooden idols (with apparent references to the Khant tradition) were built near the sacrificial stone that is a protected antiquity in the Toomemägi Park on the university campus in Tartu. ${ }^{17}$ A repertoire of regilaulud, narrative songs with lyrics in the Kalevala metre, acquired a ritual significance on gatherings of maausulised, they were performed to create a special atmosphere and a communal in-group feeling. ${ }^{18}$ But the most powerful and inclusive expressive performances of maausulised were ceremonial incantations, which turned into impressive public manifestations. Tõlet organized incantation rites at summer solstice celebrations, at consecrations of sacred groves and sacrificial stones, and some of them were deliberately arranged as large-scale public events.

\section{Recontextualized ritual practice}

The elements of cultural expression appropriated in this process were perceived as representative symbols of the vernacular past of modern Estonians, deriving directly from the imagined ritualistic commonalities of the ancient Finno-Ugrians. These activities and elements of expressive culture served as a representation of the continuity of ancient cultural heritage. A cultural heritage thus recontextualized, however, is a modern cultural production where phenomena displayed as archaic are publicly displayed. Such an exposition in order to mediate the past transforms a particular object into cultural heritage. But the process of heritage construction unavoidably makes the object perceived as heritage more ideal than historical reality could ever

\footnotetext{
${ }^{17}$ They were carved from fallen trees; to raise the biggest of them required the strength of 10 men. They stood on the hill of Toomemägi for four years, until in 1992 fanatic members of the charismatic religious sect Elu Sõna (Word of Life) pulled them down and destroyed them (Leete 1992).

${ }^{18}$ Among their favourites were Venna sõjalaul 'Brother's Song of War', Päeva veeretamine 'A Song to the Sunset', Suur tamm 'The Great Oak', Nuttev tamm 'The Weeping Oak', etc.
} 
have been: the sloppiness of experienced reality is turned into something perfect in form and shape, making it representational (Kirshenblatt-Gimblett 1998a, 7-8). Different phenomena and objects are worked into ethnographic representations through a process of fragmentation and contextualization, through which those objects are defined, taken apart, detached from their environment and placed in a new socio-cultural situation. ${ }^{19}$ Hence from the detached and highlighted fragments an abstraction is created: a new entity that has not existed previously. Elements of expressive culture perceived as heritage are decontextualised, in order to recontextualise them in a novel situation of representation. ${ }^{20}$

The most spectacular performances of public incantation rites occurred in Estonia during the period of conspicuous dissemination of maausk at the end of the 1980s and the beginning of the 1990s. For the wider audience it was actually quite often an undefined combination of healing practices, neoshamanism, Oriental studies, environmentalism and a search for genuine Finno-Ugrianism. The coercive period of an aggressive 'communist atheism' had left a religious void that became drastically emphasised under the conditions of turbulent social and political transitions. In search for a new mental and spiritual identity - or for the 'lost' one, as it was often perceived, people turned to the "essence of the Estonian national character", to the oldest layers of ethnic religion (Kõiva 1995, 215). There was a powerful upsurge of interest towards folk medicine, folk healers and sages, combined with a general idealization of the pastoral heritage, rural life and harmonious co-existence with nature that were considered the core elements of Estonian identity. Due to the alienation from official Christianity, the social status and significance of clerical institutions was low, and the idea of a primeval indigenous religion appeared more than attractive. Some influential and legendary neo-shamanic healers who had already gained respect in an earlier period now rose to the position of national heroes, attracting wide audiences to public lectures and

\footnotetext{
${ }^{19}$ For reference, see the discourse on heritage construction in Kirshenblatt-Gimblett 1998b.

${ }^{20} \mathrm{On}$ the issues of the complicated process of the presentation of tradition in the re-positioned context of metadiscursive practices, see Charles L. Briggs (1993).
} 
ritual gatherings (e.g., nõidade kokkutulek 'convention of witches', Maaema mess 'fair of Mother Earth', etc.). The most prominent among them, Vigala Sass, created his own religious doctrine from his personal interpretations of elements from the Estonian mythology or the Finnish-Karelian epic, Kalevala, while his rites were inspired by Nganasan and Altai shamanistic practices (Kõiva 1996, 220). Vigala Sass built a special loitsuplats 'incantation venue' at his farm on the Saaremaa Island: the cult site was surrounded by wooden Celtic crosses of several meters high and wooden gongs with magic symbols, while in the outer circle stood a traditional village swing, ${ }^{21}$ a sacrificial stone and a Finno-Ugric conical tent with an inside fireplace. Together with Vigala Sass, Tõlet members rallied public incantation rituals; the most massive of them was the so-called restoration of the sacred grove at Samma (Northeastern Estonia) in May 1989 when a hundred and fifty oak trees were transplanted under the supervision of ESP experts. Another great public event was the unveiling of a memorial stone to a local nõid or 'witch', Kongla Anne, ${ }^{22}$ in the same region the next year. People formed a magic circle and followed Sass in single file and repeated the incantation performed by Vigala Sass to the beating of a shamanic drum:

$\begin{array}{ll}\text { Loodus meie isa } & \text { Nature our father } \\ \text { Meie sinu lapsed } & \text { We are your children } \\ \text { Hõimu vaimu nimel } & \text { In the name of the spirit of the tribe } \\ \text { hoia meid } & \text { Protect us }\end{array}$

(Toomet \& Leete 1992)

The maausulised performed massive incantation rites, usually initiated by Tõlet activists, also in Tartu on the hill of Toomemägi or in the City Hall Square. In November, 1992, the maausulised were awarded surprising official recognition when Tõlet performed a public incantation ritual in the Parliament of the Estonian Republic. This occurrence testifies ambiguously to the fluidity and inventiveness of cultural expression under the circumstances

\footnotetext{
${ }^{21}$ A swing had strong ritual significance in Estonian folklore.

${ }^{22}$ Kongla Anne was burnt at the stake after a witch trial in 1640.
} 
of great socio-political transitions and the overwhelming contestation of previously established identities.

In the general paradigm of Estonian culture loits or 'incantation' and loitsimine or 'the act of incantation' have been applied as symbolic images of the genuine, pristine, Estonian spirit, also implemented in creating a ceremonial and solemn atmosphere on occasions of relevant significance. For such purposes have been used the choral work Pikse litaania 'A Litany to Thunder' performed at the national song festivals, the large-scale dance composition Tule loits 'Incantation to Fire' at the national dance festivals, or another choral work by Veljo Tormis Raua needmine 'The Curse of the Iron', and a number of other compositions. In the following passages, recorded in the Estonian Folklore Archives, two informants describe their personal experience of the overwhelming empowerment of an incantation, which at the same time reflects upon the impact of maausk among those consciously interested in folk traditions, students of the folklore courses for cultural animators:

Prayer to the Sun on Kihnu Island in the summer of 1989.

It was a dim afternoon of a rainy day, so dim that we had to switch on the lights to continue with our workshop at the Kihnu Cultural Centre. All of a sudden there was a power-cut and the lights went out. Someone came up with the idea of performing an entreaty to the Sun to come out again and let us continue our work. We stood in a circle and took up "A Prayer to the Sun", a song from Viljandi County. In the lyrics, the Sun was offered several tasty goodies if it came out from behind the clouds. To our utter amazement only a few minutes after the end of our singing the sun came out indeed - for the first time that day. The surprise left all the participants spellbound.

Prayer to the Rain in the spring of 1990 in Antsla (Southern Estonia).

The Folklore School was on its traditional spring tour in Southern Estonia. We were singing and dancing at the Antsla Cultural Center. In our group there was also one man who had participated in the prayer to the sun. ${ }^{23}$ He asked for our help in performing a prayer to the rain, since a severe draught had lasted for two weeks in that region already. He had proposed 
the same in Värska a few days earlier, but then I was too hesitant to perform the incantation and fortunately circumstances had ruled it out. This time, however, there was no pretext to postpone it. While I was trying, in a flurry, to recall a suitable song, Grete, the little daughter of one of the workshop participants, started a song from Põlva County "Brother Rain”. I picked up the tune and continued with an improvised appeal to the rain to be friendly and come for the rescue of people in distress. I cannot remember the exact words. Afterwards, a local man commented that if we were to succeed, we would be genuine witches. I felt very nervous the whole evening; it was as if I had taken a tremendous responsibility. I watched the news on TV but the weather forecast did not promise any rain. However, a patter of rain against the window woke me up during the night. It was the first rain in two weeks - and it came precisely after we had performed the incantation! I was bewildered, but happy.

(RKM I 26, 273/6 < Viljandi, 1991)

\section{Contested identities of modernity and the ideology of singularity}

An interest in folk traditions, their reinvention in modern life and maausk often appear combined in the formation of the core concepts of the imagined original Estonian identity. Manifested maausk ideals include "harmonious country life in a homestead, closeness to nature and environmentalist attitude"; proximity to nature is perceived as something utterly "natural, since the identity is based on folk tradition that mostly stems from peasant environment" (Västrik 1996, 95). Maausulised regard highly, and aspire to maintain, traditional handicraft skills, which would include the crafting of dugout boats or the construction of log houses, but also skills in smithy, pottery, brewery, weaving, knitting, etc. They have postulated their world outlook as an integral and holistic perception of nature and humans, defined through ethnic tradition:

Heathenism is a way to see and feel the world through tradition, to keep in mind one's ancestry and descent, to be alternative, different and indepen-

\footnotetext{
${ }^{23}$ Described in the previous text. Translations are mine.
} 
dent. It is a possibility to experience communion, /---/ a primordial power and will. This is a knowledge "picked up" from other people, trees, stones, animals, winds, songs, the murmur of waters, the soughing of trees and an infinite number of other sources. (ibid.)

To a remarkable extent maausk ideology appears to resemble the Western neo-pagan and New Age movements, or in general the movements of counterculture that seek alternatives to Christianity or to the other dominant world religions. There are observable parallels to such reconstructions of religious cultures and identities as Odinism or Ásatrú, Druidism, Church of All Worlds, and Wicca. ${ }^{24}$ However, the majority of maausulised from the period described seemed ignorant of these similarities or derivations, or were unaware of their existence, but cherished the earnest conviction that they were reviving an ethnic religion, equivalent to the concept of identity. The proponents of the movement that have actively engaged in publicising their religious perception argue that their world outlook differs in form and essence from the Western phenomena. In his discussion of maausulised, Västrik rejects the term 'neo-paganism' in favour of 'heathenism' by proposing that the emergence of such alternative movements after the fall of communism is not a reflection of Western neo-pagan ideas, but a development parallel to other post-communist East European countries. He indicates that in the Baltic countries "heathen movements have been closely linked with national 'awakening' and identity" (Västrik 1996, 97).

When discussing maausk, it is difficult to provide any fixed numbers of adherents. Before 1940, the number of Taara worshippers was estimated to be 700 , with the occasional mention of 17,000 supporters, although that has been considered an exaggeration in later accounts. During the sixties, seventies or the eighties no official records were kept on either Taara or maausulised in Estonia for obvious security reasons, but also due to an ideological grounding that any lists and accounts of written form would be alien to the essence

\footnotetext{
${ }^{24}$ Cf. maausk and Earth religion, Maaema and Mother Earth; worship of Maaema and the Gaia hypothesis (see Västrik 1997, 47).
} 
of their belief system. ${ }^{25}$ The first officially registered association of maausulised was the Heritage Protection Club Tõlet, and yet even they refrained from any organized documentation. The founder members included about two dozen people who had a charismatic impact on considerably greater numbers, as they regarded their public objective to be an active promotion of their creed, while simultaneously enjoying open publicity. Although the leading activist group of maausulised has been predominantly male, the percentage of females among worshippers seemed to be even larger. If the activities of Tõlet mostly attracted the younger generation opposed to the mainstream, then the incantation rites carried out by Vigala Sass attracted large numbers of people of all ages. At the so-called public incantation rites, or avalikud loitsud, hundreds of people participated. From Tõlet there branched off some relatively extremist trends of heathenism, for example, the Association of Ancient Shamanic Wisdom, and similarly to Tõlet, they were actively disseminating their ideology via the internet. On the web there appeared long programmatic tractates on their philosophy and doctrine, carrying such headings as: Terror, Horror, Heresy, and Anarchy. ${ }^{26}$ Tõlet as an organization has ceased to exist, but their publications, their songbooks and their incantations have been available on the web. Today, the prevailing mentality and concept of maausk is declared to have changed into "a more self-absorbed and meditative, pluralist view of heathenism" (Västrik 1996, 93). In the spring of 1995, congregations of maausk and Taara usk were officially registered as Maavalla Koda, 'Hall of People of the Land', and consequently the Heritage Protection Club Tõlet terminated their activities.

It must be concluded, however, that by becoming a registered religious association, maausulised undoubtedly entered the wider and mainstream social discourse of ideology and power that they could abstain from acknowledging in the earlier period. The official lists include a couple of hundred people with an 'imagined community' of sympathizers numbering consid-

\footnotetext{
${ }^{25}$ They tacitly assumed that every Estonian might be considered a maausuline.

${ }^{26}$ Such aggressive negativism suggests a parallel to neo-Nazi sympathizers, though it probably functions on the same level of empowering machoist appeal with the cults of Odin or Ásatrú without concrete actions, though claims for ethnic purity are disturbingly present.
} 
erably more. ${ }^{27}$ But this process of institutionalisation has likewise denoted written introductions and manifestos of doctrines, although publicly voiced adherents have suggested that this practice is in contradiction of their beliefs. Any ideology nevertheless aims at conducting and controlling the social situation and cultural politics, in order to justify or change the socio-political or cultural process, while a particular collective goal is formulated and communicated on a public arena. On the other hand, ideology requires the organisation of a particular system of cultural symbols, and it inaugurates the mapping of instrumental symbolic signs and landmarks to define the identity being championed (cf. Freeden 2003; Bloch 2002; Byron 2002). The maausulised of Estonia have manifested their ideology of vernacular religion now for a decade also via the internet, while their visibility on the social scene underwent a period of marked decline in comparison to the activism previously described. The socio-political circumstances introduced by the marked orientation towards liberal capitalism and collective aspirations towards speedy integration with the West subsequently marginalised the status of countercultural tendencies among the general public. But the tables have apparently been turned again with Estonia becoming a full member of the European Union, which has partly coincided with a shift of leadership among the ranks of the maausulised, whose new advocates demand a more active presence, particularly in the media. The decisive impact of leadership on the ideology promoted makes itself instrumental once again. The most recent developments, however, remain to be discussed in another article. Nevertheless, if some ritual aspects or social contexts have changed, ${ }^{28}$ the perception and ideals of maausulised as publicised on their website or in other publications resonant strongly with the convictions previously described above: the inherent conception of maausk reflecting the original vernacular worldview, proclaimed contingent singularly on the territory of Estonia as the only genuine belief system of the põlisrahvas 'indigenous people' of

\footnotetext{
${ }^{27}$ Here is noticed again a similarity with the western movements where the numbers of congruents tend to be small, remaining around hundred and rarely exceeding a couple of thousands (Hinnels 1984, 232).

${ }^{28}$ E.g., a surprisingly vehement denial of shamanic drumming.
} 
Estonia, which is an automatic equivalent of maarahvas. Thus maausk was never created by anyone but evolved among innumerable generations; it forms an integrated whole with an inherited culture, land and language, thus constituting more than a religion, something which cannot be expressed in words but requires enlightenment on a personal level. It has to be inherited at home, searched for in archival collections or museums or old chronicles, whereas one's approach to ancient tradition has to be selective: the "precious and essential" still need to be "washed out like gold" from varied cultural material. ${ }^{29}$

An adverse stance towards the West is manifest from several perspectives. The only acceptable influence on ritual practices is claimed to be the Finno-Ugrian one, as maausk forms an "integral family with the vernacular religions of other Uralic peoples". The ancient ties are re-affirmed, but this process still accedes to the wider sphere of selfhood construction. The empowering self-image of Estonians as a kindred nation among other FinnoUgrians continues to be instrumental in establishing personal identities in opposition to the homogeneity of global mass culture and the emergent hegemony of the newly indoctrinated 'European culture'. Finno-Ugrianism persists in carrying a message of alternative identity, but under the changed socio-political circumstances with Estonian culture as the dominant mainstream, it likewise supports the constitution of local identities (e.g., those of the Võru or Setu). ${ }^{30}$ In the discourse of cultural selfhood in Estonia today, in the current context of identity negotiations where the dynamic mainstream is oriented towards Europe, Finno-Ugrianism - with the tacit inclusion of the vernacular religious concepts of maausk - appears to be reassuming the status of the value-laden reserve of genuine Estonian identity.

\footnotetext{
${ }^{29}$ The document cited is available on the website http://www.maavald.ee/

${ }^{30}$ The Setus have been incorporated in Finno-Ugric political organizations as an independent ethnic group.
} 
Bibliography

Anttonen, Pertti J.

1996 Introduction: Tradition and Political Identity. - Pertti J. Anttonen (ed.), Making Europe in Nordic Contexts, 7-40. Turku: Nordic Institute of Folklore.

Bloch, Maurice

2002 Ideology. - Aland Barnard \& Jonathan Spencer (eds), Encyclopedia of Social and Cultural Anthropology, 293-294. London \& New York: Routledge.

Briggs, Charles L.

1993 Metadiscursive Practices and Scholarly Authority in Folklore. - Journal of American Folklore 106 (422), 387-434.

Byron, Reginald

2002 Identity. - Aland Barnard \& Jonathan Spencer (eds), Encyclopedia of Social and Cultural Anthropology, 292. London \& New York: Routledge.

Eller, Kalle I.

1990 Maarahvast. - Vikerkaar 3, 72-77.

1991 Intervjuu Kalle Elleriga. - Kultuur ja Elu 3, 12-17.

Freeden, Michael

2003 Ideology: A Very Short Introduction. Oxford: Oxford University Press.

Friedman, Jonathan

1992 The Past in the Future: History and the Politics of Identity. - American Anthropologist 94 (40), 837-859.

1994 Cultural Identity and Global Process. London: Sage.

Frykman, Jonas

1995 The Informalization of National Identity. - Ethnologia Europaea 25 (1), 5-15.

Giddens, Anthony

1991 Modernity and Self-Identity: Self and Society in the Late Modern Age. Cambridge: Polity.

Handler, Richard \& Jocelyn Linnekin

1984 Tradition, Genuine or Spurious. - Journal of American Folklore 97 (385), 273-290.

Hinnells, John R.

1984 New Religious Movements in the West. - John R. Hinnells (ed.), The Penguin Dictionary of Religions, 232-233. London: Penguin Books. 


\section{Hobsbawm, Eric}

1983 Introduction: Inventing Traditions. - Eric Hobsbawm \& Terence Ranger (eds), The Invention of Tradition, 1-14. Cambridge: Cambridge University Press.

\section{Hughes, H. Stuart}

1977 Consciousness and Society: The Reorientation of European Social Thought 1890-1930. New York: Vintage Books.

Kaasik, Ahto

1993 Ahto jutt. - Hiis 6 (lehekuu 10206), 2-8.

\section{Kirshenblatt-Gimblett, Barbara}

1998a Introduction. - Destination Culture: Tourism, Museums, and Heritage, 113. Berkeley-Los Angeles-London: University of California Press.

1998b Objects of Ethnography. - Destination Culture: Tourism, Museums, and Heritage, 17-78. Berkeley-Los Angeles-London: University of California Press.

\section{Kõiva, Mare}

1995 From Incantations to Rites. - Mare Kõiva \& Kai Vassiljeva (eds), Folk Belief Today, 215-236. Tartu: Estonian Academy of Sciences.

1996 The Transmission of Knowledge Among Estonian Witch Doctors. - Folklore 2, 41-72.

\section{Kymme aastat}

1988 Kymme aastat nyydisaegseid sirvilaudu. - Vikerkaar 1, 49-54.

Leete, Art

1992 Puuslikud Toomemäel. - Hiis 5 (jõulukuu 10205), 20-22.

\section{Primiano, Leonard}

1995 Vernacular Religion and the Search for Method in Religious Folklife. - Western Folklore 54, 37-56.

\section{Pūtelis, Aldis}

1997 Folklore and Identity: The Situation of Latvia. - Folklore 4, 61-76.

\section{Ramoškaitè-Sverdioliené, Živilè}

1996 Archaic Folklore Elements in Contemporary Everyday Life. - Mare Kõiva (ed.), Contemporary Folklore, 79-85. Tartu: Institute of the Estonian Language \& Estonian Museum of Literature.

\section{Rüütel, Ingrid}

1997 Estonian Folk Music Layers in the Context of Ethnic Relations. - Folklore 6, 32-69.

Sarv, Tõnn \& Kalle Eller

1987200 maakeelset nime. - Kultuur ja Elu 9, 21-22. 


\section{Stromberg, Roland N.}

1994 European Intellectual History since 1789. New Jersey: Prentice-Hall.

\section{Suni, Raivo}

1998 Eesti kultuurilise teadvuse muutumine aastatel 1990-1997. - Sirp 41 (2746), 06.11., 3-4.

Tedre, Ülo

1995 About the Life and Work of an Eccentric. - Mare Kõiva \& Kai Vassiljeva (eds), Folk Belief Today, 457-468. Tartu: Estonian Academy of Sciences.

Toomet, Lauris \& Art Leete

1992 Tõleti avalikud loitsud 1. - Hiis 5 (jõulukuu 10205), 9-13.

Tõlet

1992 Tõlet. - Hiis 5 (jõulukuu 10205), 40.

Viires, Ants

1990 Taara avita! - Looming 10, 1410-1421.

Viires, Ants \& Ülo Tedre

1998 Uurimislugu. - Ants Viires \& Elle Vunder (eds), Eesti rahvakultuur, 15-45. Tallinn: Eesti Entsüklopeediakirjastus.

\section{Västrik, Ergo-Hart}

1996 The Heathens in Tartu in 1987-1994: Heritage Protection Club Tõlet. - Mare Kõiva (ed.), Contemporary Folklore, 86-101. Tartu: Institute of the Estonian Language \& Estonian Museum of Literature.

1997 Lääne uuspaganluse piirjooni. - Mäetagused 3, 41-52. 